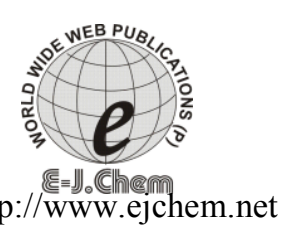

ISSN: 0973-4945; CODEN ECJHAO

E-Journal of Chemistry

2012, 9(3), 1244-1250

\title{
Effects of Zinc Binding on the Structure and Stability of Glycylglycine Dipeptide: a Computational Study
}

\author{
MOHAMMAD T. BAEI, ${ }^{*}$ S. ZAHRA SAYYED-ALANGI \\ Departments of Chemistry, Azadshahr Branch, Islamic Azad University, Azadshahr, \\ Golestan, Iran \\ Baei52@yahoo.com
}

Received 24 October 2011; Accepted 30 December 2011

\begin{abstract}
Energies and structures of six different isomers resulted of complex between glycylglycine dipeptide and zinc cation were calculated at the BLYP and B3LYP levels of theory with $6-311 \mathrm{G}^{* *}$ and $6-311++\mathrm{G}^{* *}$ basis sets. The energies of the glycylglycine- $\mathrm{Zn}^{2+}$ different complexes at the BLYP/6$311++\mathrm{G}^{* *}$ obtained more stable than another methods. In this method, the most stable complex was zinc cation bound to the two oxygen sites of the glycylglycine zwitterion and acted as a bidentate ligand. The vibrational frequencies, thermodynamic and electronic properties, HOMO, LUMO, and energy gap for the most stable isomer in different solvents were calculated at the BLYP/6-311++G** level of theory.
\end{abstract}

Keywords: DFT calculations, Glycylglycine- $\mathrm{Zn}^{2+}$, Enthalpy, HOMO, LUMO.

\section{Introduction}

Amino acids are one class of interesting and important compounds in life, and have many functions in metabolism ${ }^{1}$. One particularly important role is to serve as the building blocks of proteins ${ }^{1}$. In recent years, studies of the interaction of a metal cation with amino acids have been the subject of considerable attention ${ }^{2-18}$ and many investigations have also been done about determining thermodynamical quantities of protein structures ${ }^{19}$. Complexation modes between cations and amino acids in cation-peptide systems are important in biological processes such as cellular osmotic equilibrium control or in active transport phenomena ${ }^{20-22}$. Also, metallic cations influence on the three-dimensional structure of nucleic acids ${ }^{23-27}$. There are different sites of complexation in peptides including the Nterminus nitrogen atom and the carboxylate group at the C-terminus end, and the oxygen or nitrogen atoms which present in the main chain or in the lateral ones. The recognition of the essence of the interactions cation-peptide provides us the important information on the role of important biological molecules ${ }^{28}$. The coordination modes of cations are very strongly with the sites which they interact. Some metals have a strong relation for specific coordination modes, particularly in metalloenzymes ${ }^{29}$. Some others may pursue indifferently 
several coordination modes ${ }^{30}$. In this manuscript, we were considered the different formed complexes between the glycylglycine dipeptide and zinc cation $\left(\mathrm{Zn}^{2+}\right)$. Then, we identified the most stable glycylglycine- $\mathrm{Zn}^{2+}$ isomer and calculated the vibrational frequencies, thermodynamic properties and electronic properties it in different solvents.

\section{Computational Methodology}

Geometries of various isomers of glycylglycine $-\mathrm{Zn}^{2+}$ were fully optimized using the Gussian $98^{31}$. The computations were performed within the formalism of the density functional theory (DFT), at the BLYP and B3LYP levels and the 6-311G** and 6$311++\mathrm{G}^{* *}$ extended basis sets ${ }^{30}$. All the structures were obtained without any geometry constraint in order to identify the most stable isomer. The absence of any imaginary vibrational frequency was verified to be sure that each stationary point was a true minimum. We investigated vibrational frequencies, enthalpy, entropy, Gibbs energy, electronic properties, HOMO, LUMO, and energy gap for the most stable isomer in different solvents at the BLYP/6-311++G** level of theory.

\section{Results and Discussion}

\section{Structures and relative stability}

We fully optimized I-IV structures (glycylglycine- $\mathrm{Zn}^{2+}$ different complexes) at the BLYP and B3LYP levels with $6-311 \mathrm{G}^{* *}$ and $6-311++\mathrm{G}^{* *}$ basis sets. The obtained results were represented on Fig. 1 and energetic data were collected in Table 1 and Table 2.

Structures and energetic of obtained complexes of glycylglycine dipeptide and zinc cation at the BLYP/6-311++G** method had more stable than another methods. Our computations showed that $\mathbf{V}$ isomer was the most stable isomer (Table 1). In the most stable complex ( $\mathbf{V}$ isomer), zinc cation was bound by the two oxygen sites of glycylglycine zwitterion and acted as a bidentate ligand (Fig. 1).

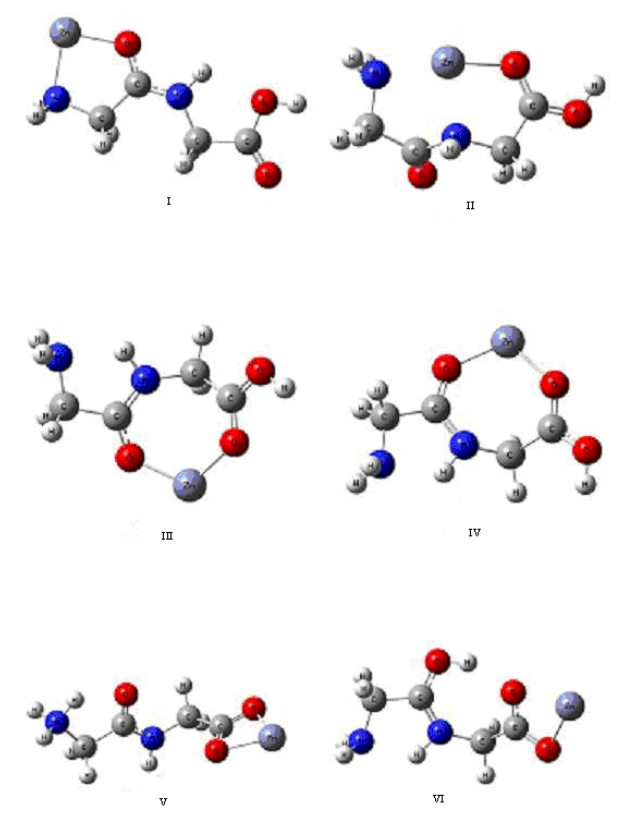

Figure 1. Optimized structures of glycylglycine $-\mathrm{Zn}^{2+}$ complexes. 
Difference of relative energies between structures II and $\mathbf{V}$ was very low (Table 1 and 2). In the BLYP/6-311G** and BLYP/6-311++G** levels, $\mathbf{V}$ isomer had more stable than II isomer about 2.326 and $1.010 \mathrm{kcal} / \mathrm{mol}$, respectively (Table 1). But, at the B3LYP/6-311 G** and B3LYP/6-311++G** levels, relative energies of $\mathbf{V}$ isomer obtained 1.606 and 2.974 $\mathrm{kcal} / \mathrm{mol}$ higher than II isomer, respectively (Table 2).

Table 1. Energies (Hartree) and Relative Energies (kcal/mol) of Optimized Isomers (BLYP/6-311G**, 6-311++ $\mathrm{G}^{* *}$ ) of the Isolated Glycylglycine- $\mathrm{Zn}^{2+}$ Complexes in Gas Phase.

\begin{tabular}{c|c|c|c|c}
\hline Isomers & BLYP(6-311G**) & $\begin{array}{c}\text { Relative } \\
\text { energy }\end{array}$ & BLYP(6-311++G**) & Relative energy \\
\hline V & -557.623 & 0.000 & -557.640 & 0.000 \\
II & -557.619 & 12.538 & -557.638 & 1.010 \\
III & -557.603 & 18.623 & -557.623 & 10.617 \\
I & -557.593 & 18.769 & -557.612 & 17.224 \\
IV & -557.593 & 21.901 & -557.613 & 16.705 \\
VI & -557.588 & -557.608 & 19.937 \\
\hline
\end{tabular}

Table 2. Energies (Hartree) and Relative Energies (kcal/mol) of Optimized Isomers (B3LYP/6-311G**, 6-311++G**) of the Isolated Glycylglycine- $\mathrm{Zn}^{2+}$ Complexes in Gas Phase.

\begin{tabular}{c|c|c|c|c}
\hline Isomers & B3LYP(6-311G**) & Relative energy & B3LYP(6-311++G**) & Relative energy \\
\hline II & -557.424 & 0.000 & -557.444 & 0.000 \\
V & -557.421 & 1.606 & -557.439 & 2.974 \\
III & -557.407 & 10.682 & -557.428 & 9.958 \\
IV & -557.397 & 16.743 & -557.418 & 15.909 \\
I & -557.391 & 20.356 & -557.411 & 20.291 \\
VI & -557.386 & 23.673 & -557.407 & 22.935 \\
\hline
\end{tabular}

Difference energy between these geometries was small enough to anticipate a possible equilibrium between several structures at high temperature. One notices that these results could hardly be extended into another polypeptides or proteins. The energy for the most stable isomer in different solvents was calculated at the BLYP/6-311++ $\mathrm{G}^{* *}$ level of theory (Table 3). The geometry energy was very sensitive to dielectric constants and increased in the high dielectric constants.

Table 3. Energies (Hartree) and Relative Energies (kcal/mol) for V Isomer at the BLYP/6$311++\mathrm{G}^{* *}$ level in Different Solvents.

\begin{tabular}{c|c|c|c}
\hline Solvent & $\varepsilon$ & Energies (Hartree) & relative energies $(\mathrm{kcal} / \mathrm{mol})$ \\
\hline $\mathrm{H}_{2} \mathrm{O}$ & 78.390 & -2271.282 & 0 \\
$\mathrm{DMSO}$ & 46.700 & -2271.274 & 5.090 \\
$\mathrm{CH}_{3} \mathrm{OH}$ & 32.630 & -2271.271 & 6.935 \\
$\mathrm{CH}_{3} \mathrm{CH}_{2} \mathrm{OH}$ & 24.550 & -2271.265 & 10.711 \\
\hline
\end{tabular}

\section{Vibrational frequencies}

The vibrational frequencies were calculated at the BLYP/6-311++G** level of theory. We scaled the vibrational frequencies for the most stable state ( $\mathbf{V}$ isomer in Fig. 1) and used to 
simulate the IR spectra (Fig. 2) in different solvents. The simulated IR spectra could be used as evidence to identify the most stable isomer state (case $\mathbf{V}$ in Fig. 1). The absence of imaginary vibrational frequency confirmed that the most stable isomer corresponded to true minima.
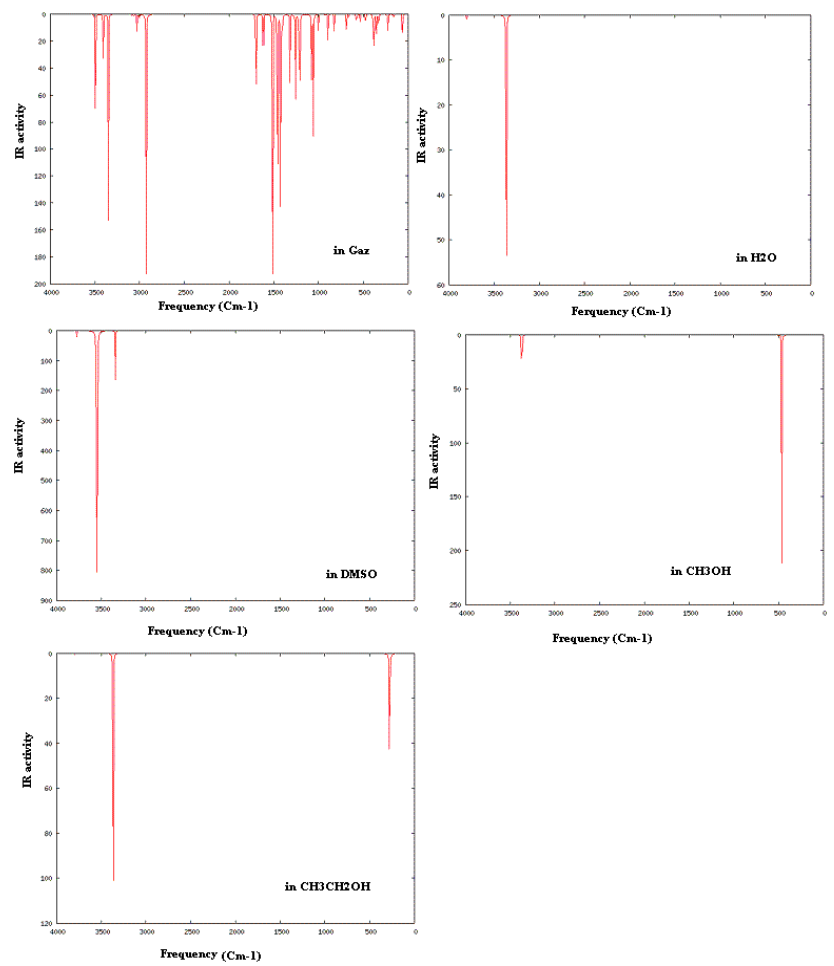

Figure 2. Simulate the IR spectra for the most stable state (V isomer in Fig. 1) in different solvents. IR spectrum scaled by 1.000000 .

\section{Thermodynamic changes}

The thermodynamic changes for the most stable isomer (isomer $\mathbf{V}$ in Fig. 1) were estimated using total energies obtained at the BLYP/6-311++ $\mathrm{G}^{* *}$ method. The thermodynamic properties were calculated from the standard statistical mechanical equations to include the finite-temperature translational, rotational and vibrational energies [32]. For example, the enthalpy $(\mathrm{H})$ was obtained as follows:

$$
\mathrm{H}=\mathrm{E}_{\text {elec }}+\mathrm{E}_{\mathrm{vib}}(\mathrm{T}=0)+\mathrm{E}_{\mathrm{vib}}(\mathrm{T})+\mathrm{E}_{\mathrm{rot}}(\mathrm{T})+\mathrm{E}_{\text {tra }}(\mathrm{T})+\mathrm{PV}
$$

where $E_{\text {elec }}$ was the total electronic energy at $0 \mathrm{~K}, \mathrm{E}_{\mathrm{vib}}(\mathrm{T}=0)$ was the zero-point vibrational energy which was a linear sum of the basic harmonic frequencies, and $E_{v i b}(T), E_{\text {rot }}(T)$, and $\mathrm{E}_{\text {tra }}(\mathrm{T})$ were vibrational, rotational, and translational contributions, respectively. Also, the entropy ( $\mathrm{S}$ ) of molecules could also be calculated from a standard formula:

$$
\mathrm{S}=\mathrm{S}_{\text {elec }}+\mathrm{S}_{\mathrm{vib}}+\mathrm{S}_{\text {rot }}+\mathrm{S}_{\text {tra }}
$$

Where $S_{\text {elec}}, S_{\text {vib }}, S_{\text {rot }}$, and $S_{\text {tra }}$ were the electronic, vibrational, rotational, and translational terms. The change in the standard Gibbs free energy was given by

$$
\Delta \mathrm{G}=\Delta \mathrm{H}-\mathrm{T} \Delta \mathrm{S}
$$

The thermodynamic properties for the most stable isomer (case $\mathbf{V}$ in Fig. 1) in different solvents were calculated. For this isomer, $\Delta \mathrm{H}, \Delta \mathrm{S}$, and $\Delta \mathrm{G}$ were performed at the BLYP/6$311++\mathrm{G}^{* *}$ level of theory (Table 4 ). Also, $\Delta \mathrm{H}<0$ showed that this process was exothermic. 
Table 4. $\Delta \mathrm{H}, \Delta \mathrm{S}$, and $\Delta \mathrm{G}$ in $\mathrm{kcal} / \mathrm{mol}$ for $\mathrm{V}$ isomer at the BLYP/6-311++ $\mathrm{G}^{* *}$ level in different solvents at $298 \mathrm{k}$.

\begin{tabular}{l|c|c|c}
\hline solvent & $\Delta \mathbf{H}$ & $\Delta \mathbf{S}$ & $\Delta \mathbf{G}$ \\
\hline $\mathbf{G a s}$ & -289.776 & -9.895 & -279.881 \\
$\mathbf{H}_{2} \mathbf{O}$ & -536.844 & -10.577 & -526.266 \\
DMSO & -532.851 & -10.583 & -522.268 \\
$\mathbf{C H}_{3} \mathbf{O H}$ & -531.106 & -10.354 & -520.751 \\
$\mathbf{C H}_{3} \mathbf{C H}_{2} \mathbf{O H}$ & -527.597 & -10.117 & -517.480 \\
\hline
\end{tabular}

\section{Electronic properties}

Finally, we studied changes on the electronic properties for the most stable isomer state ( $\mathbf{V}$ isomer) in different solvents and the total densities of states (DOS) of these isomers were shown in Fig.3, where Fermi energy sets to $0 \mathrm{eV}$. The HOMO, LUMO energies, and their energy gaps were listed in Table 5. The electronic properties were very sensitive to dielectric constants and increased in high dielectric constants. It is clear that the presence of solvents with the high dielectric constants increased their energy gaps and reduced the electrical conductance of the most stable state ( $\mathbf{V}$ isomer).
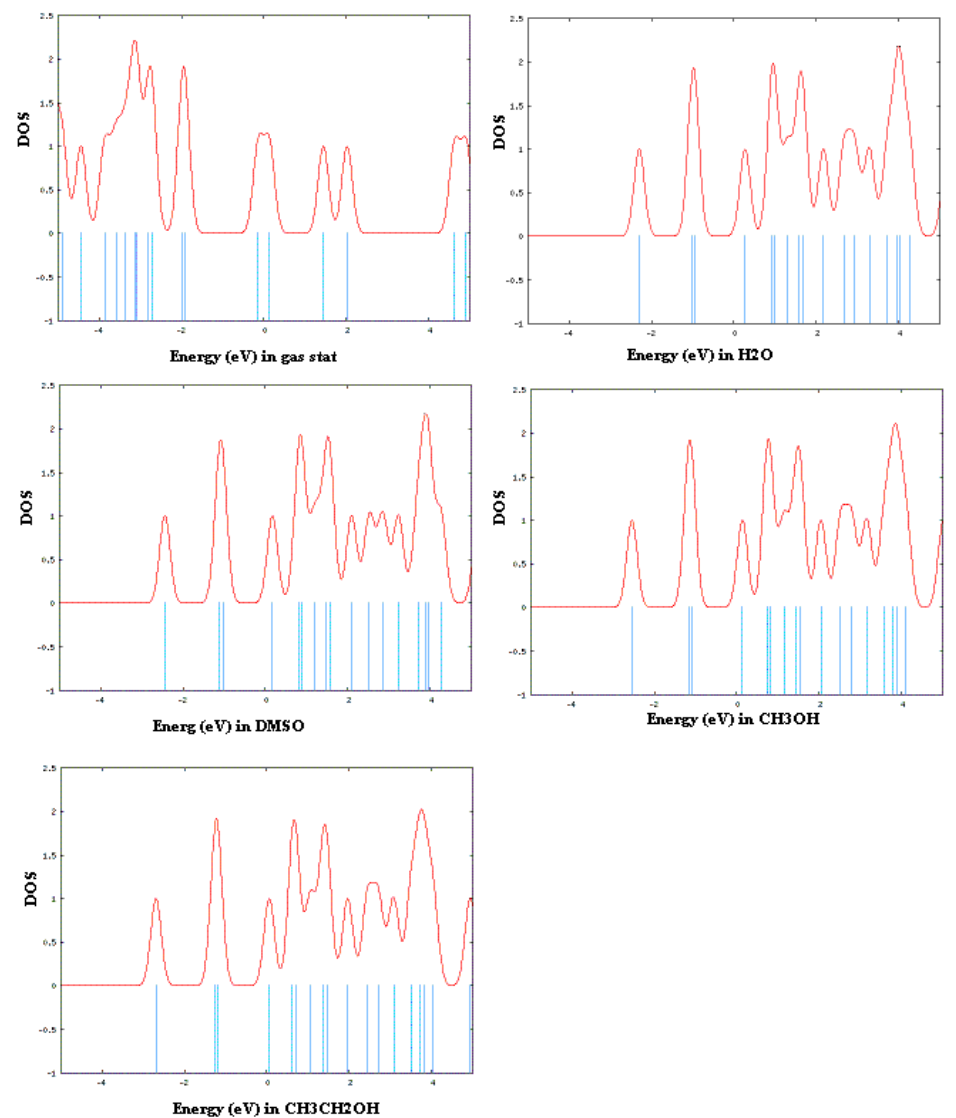

Figure 3. Electronic density of states for V isomer at the BLYP/6-311G** level in different solvents. 
Table 5. HOMO and LUMO energies and their energy gaps for $\mathrm{V}$ isomer at the BLYP/6$311 \mathrm{G}^{* *}$ level in different solvents.

\begin{tabular}{c|c|c|c}
\hline solvent & HOMO & LUMO & Energy gap (eV) \\
\hline Gas & -13.86 & -12.56 & 1.30 \\
$\mathbf{H}_{2} \mathbf{O}$ & -6.23 & -2.30 & 3.93 \\
DMSO & -6.37 & -2.44 & 3.93 \\
$\mathbf{C H}_{\mathbf{3}} \mathbf{O H}$ & -6.41 & -2.54 & 3.87 \\
$\mathbf{C H}_{\mathbf{3}} \mathbf{C H}_{\mathbf{2}} \mathbf{O H}$ & -6.51 & -2.69 & 3.82 \\
\hline
\end{tabular}

\section{Conclusion}

This study performed at a rather good computational level at the BLYP and B3LYP levels; and $6-311 \mathrm{G}^{* *}$ and $6-311++\mathrm{G}^{* *}$ basis sets. Six different glycylglycine- $\mathrm{Zn}^{2+}$ isomers were considered. The most stable isomer was zinc cation bound by the two oxygen ends of the zwitterionic dipeptide. The vibrational frequencies for the most stable isomer in different solvents were calculated at the BLYP/6-311++G** level of theory. The absence of imaginary vibrational frequency confirmed $\mathbf{V}$ isomer corresponded to true minima. According to obtained results of thermodynamic properties (enthalpy, entropy, and Gibbs energy) of $\mathbf{V}$ isomers in different solvents at BLYP/6-311++G**, the process was exothermic. Finally, we studied influence different solvents on electronic properties, HOMO, LUMO, and energy gap of the most stable isomer.

\section{References}

1. a) Styler L, Biochemistry (3rd ed.) WH Freeman, 1998.

2. Reddy A Srinivas and Sastry G Narahari, The Journal of Physical Chemistry A, 2005, 109(39), 8893-8903.

3. Grese R P, Cerny R L and Gross M L, J. Am. Chem. Soc. 1989, 111, 2835-2842.

4. Teesch L M and Adams J, J. Am. Chem. Soc., 1991, 113, 812-820.

5. Teesch L M, Orlando R C and Adams J, J. Am. Chem. Soc., 1991, 113, 3668-3675.

6. Hu P and Gross M L, J. Am. Soc. Mass Spectrom, 1994, 5, 137-143.

7. Gross D S and Williams E R, J. Am. Chem. Soc, 1996, 118, 202-204.

8. Wyttenbach T, Von Heiden G and Bowers M T, J. Am. Chem. Soc, 1996, 8355.

9. Giorgi G, Ginanneschi M, Chelli M, Papini A M, Laschi F and Borghi E, Mass Spectrom, 1996, 10, 1266-1272.

10. Klassen J S, Anderson S G, Blades A T and Kebarle P, J. Phys. Chem., 1996, 100, 14128-14227.

11. Schnier P D, Price W D, Strittmatter E F, Williams E R, J. Am. Soc. Mass Spectrom, 1997, 8 , 771-780.

12. Cerda B A, Hoyau S, Ohanessian G and Wesdemiotis C, J. Am. Chem. Soc., 1998, 120, 2437- 2448.

13. Lee S W, Kim H S, Beauchamp J L, J. Am. Chem. Soc., 1998, 120, 3188.

14. Wyttenbach T, Bushnell J E and Bowers M T, J. Am. Chem. Soc., 1998, 120, 50985103.

15. Lin T and Glish G L, Anal. Chem., 1998, 70, 5162-5165.

16. Feng W F, Gronert S and Lebrilla C B, J. Am. Chem. Soc., 1999, 121, 1365-1371.

17. Kish M M and Wesdemiotis C, Int. J. Mass Spectrom, 2003, 227, 191-203.

18. Lippard S J, Berg J M, Principles of Bioinorganic Chemistry, Mill Valley, CA, 1994, 541-543.

19. Kim C A; Berg J M, Nature, 2000, 362, 267-270. 
20. Zhang X; Yang Z; Li W; Yang L; Weng S and Wu J, Spectrochimica Acta Part A: Molecular and Biomolecular Spectroscopy, 2004, 60(1), 235-240.

21. Hughes M N, The Inorganic Chemistry of Biological Processes, second ed., Wiley, Chichester 1981. 177-181.

22. Kaim W and Schwederski B, Bioinorganic Chemistry: Inorganic Elements in the Chemistry of Life, Wiley, Chichester, 1994, 0-471.

23. Sauer J, Chem. Rev, 1989, 89, 199-255.

24. Bäckvall J E, Bökman F and Blomberg M R A, J. Am. Chem. Soc., 1992, 114, 534538.

25. Dougherty D A, Science, 1996, 271, 163-168.

26. Silagyi R K and Frenking G, Organometallics, 1997, 16, 4807.

27. Glusker J P, Adv. Protein Chem., 1991, 42, 1-76.

28. Kish M M, Ohanessian G and Wedemiotis Chrys, J. Phys. Chem. B, 2004, 108, 3086.

29. Snaith Sybil M, Biochem. J., 1975, 147, 83-90.

30. Benzakour M, Mcharifi M, Cartier A and Daoudi A, J. Molecular Structure, 2004, 710-169.

31. Frisch MJ, Trucks GW, Schlegel HB, Scuseria GE, Robb MA, Cheeseman JR, Zakrzewski VG, Montgomery JA Jr, Stratmann RE, Burant JC, Dapprich S, Millam JM, Daniels AD, Kudin KN, Strain MC, Farkas O, Tomasi J, Barone V, Cossi M, Cammi R, Mennucci B, Pomelli C, Adamo C, Clifford S, Ochterski J, Petersson GA, Ayala PY, Cui Q, Morokuma K, Malick DK, Rabuck AD, Raghavachari K, Foresman JB, Cioslowski J, Ortiz JV, Baboul AG, Stefanov BB, Liu G, Liashenko A, Piskorz P, Komaromi I, Gomperts R, Martin RL, Fox DJ, Keith T, Al-Laham MA, Peng CY, Nanayakkara A, Gonzalez C, Challacombe M, Gill PMW, Johnson B, Chen W, Wong MW, Andres JL, Gonzalez C, Head-Gordon M, Replogle ES, Pople JA (1998) Gaussian 98. Gaussian, PA.

32. Lay J.E.; Statistical Mechanics and Thermodynamics of Matter. 1st ed., Harper \& Row Publishers, New York 1990 [chapter 5]. 


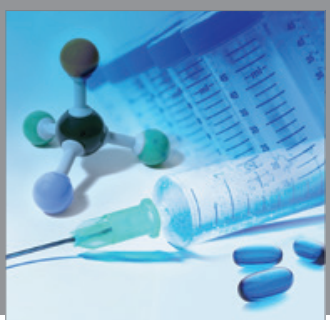

International Journal of

Medicinal Chemistry

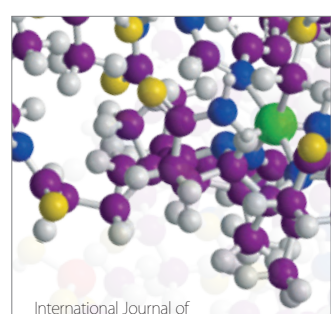

Carbohydrate Chemistry

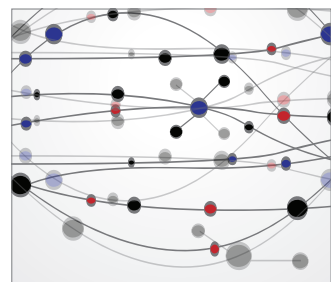

The Scientific World Journal
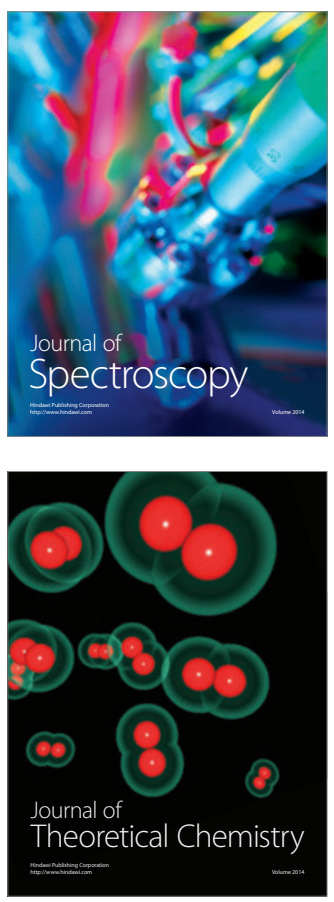
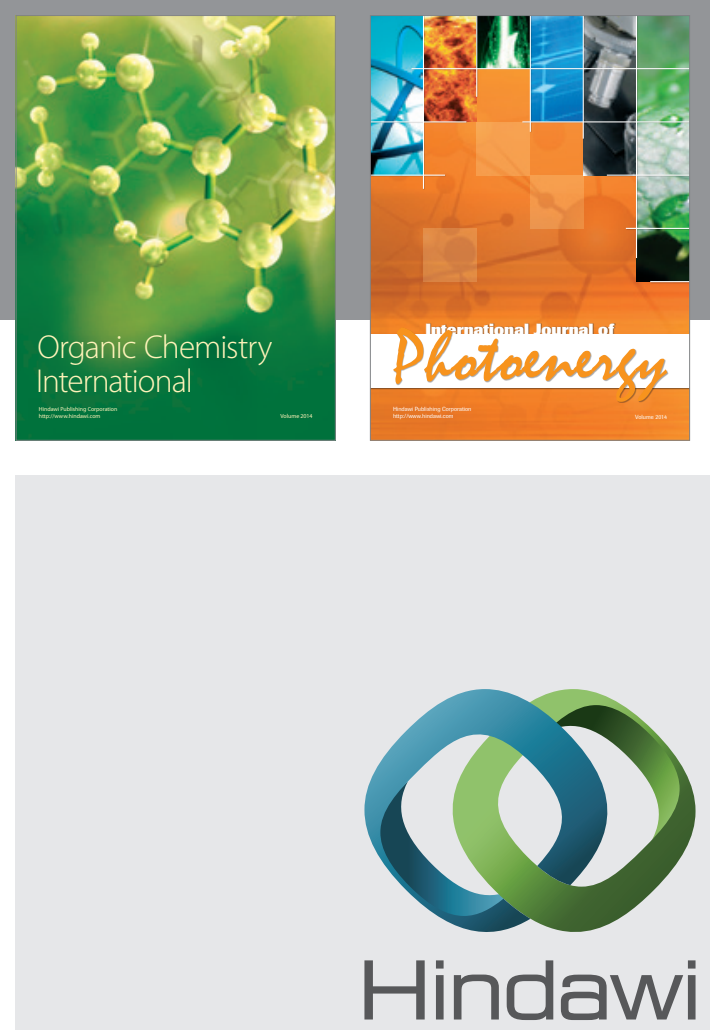

Submit your manuscripts at

http://www.hindawi.com
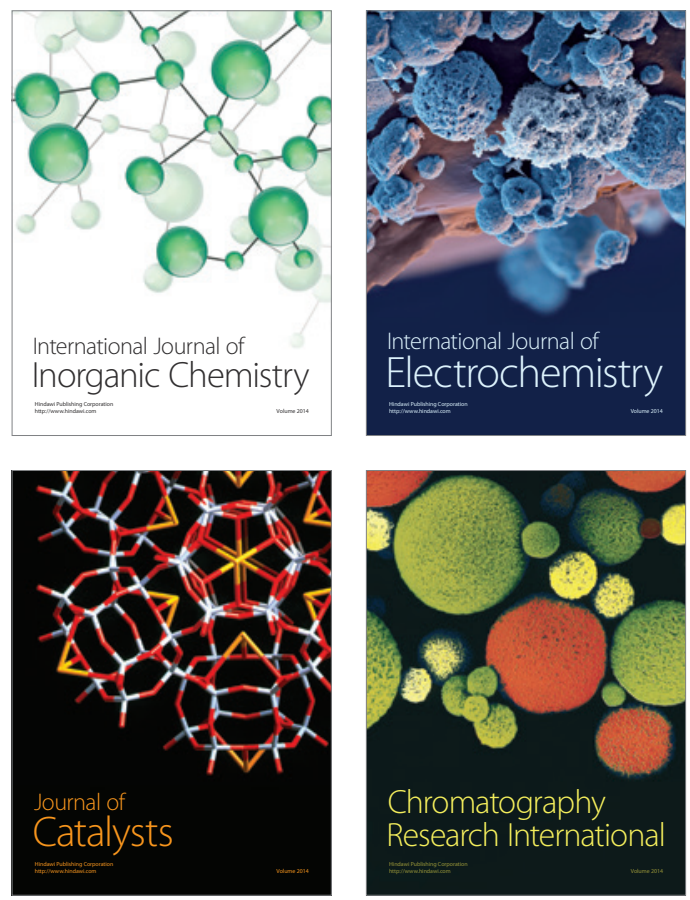
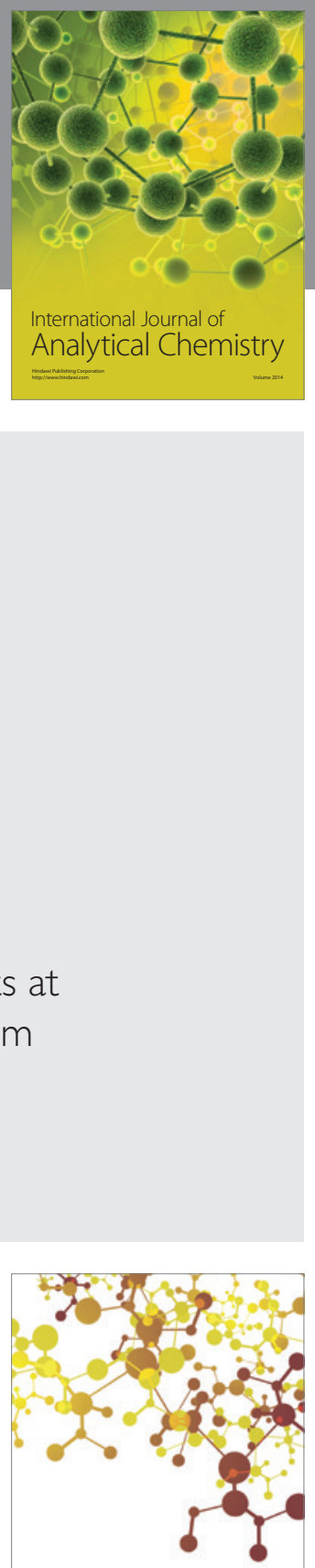

Journal of

Applied Chemistry
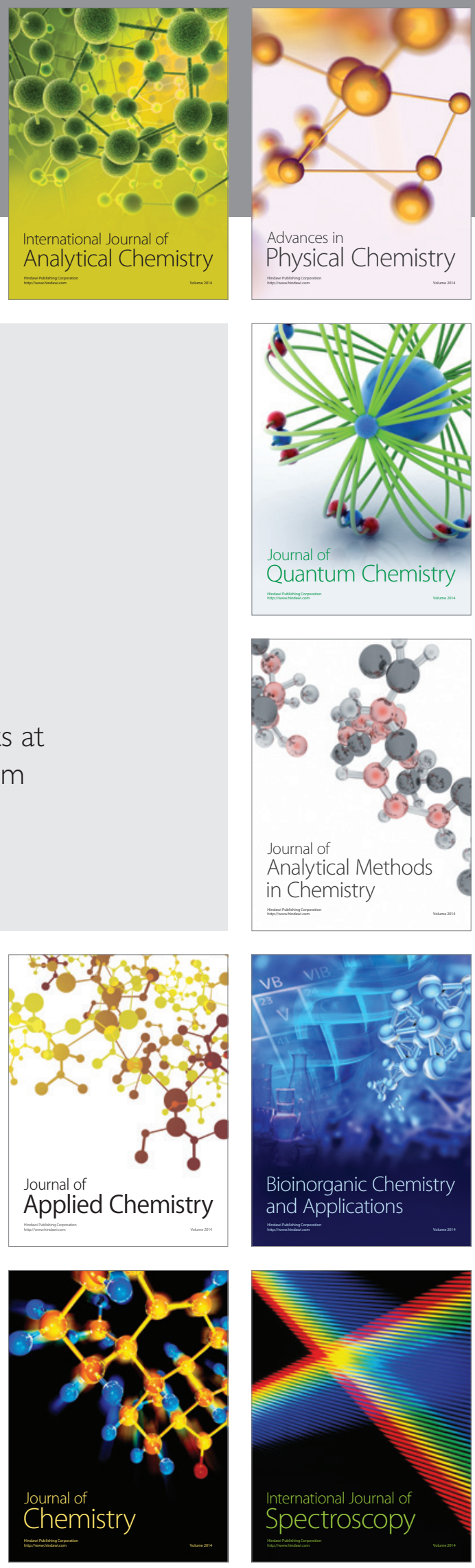